\title{
Article
}

\section{Silver Nanoparticles from Oregano Leaves' Extracts as Antimicrobial Components for Non-Infected Hydrogel Contact Lenses}

\author{
Anastasia Meretoudi ${ }^{1}$, Christina N. Banti ${ }^{1, * \mathbb{D}}$, Panagiotis K. Raptis ${ }^{1}$, Christina Papachristodoulou ${ }^{2}$, \\ Nikolaos Kourkoumelis ${ }^{3}\left(\mathbb{D}\right.$, Aris A. Ikiades ${ }^{2}$, Panagiotis Zoumpoulakis ${ }^{4}$, Thomas Mavromoustakos ${ }^{5}$ (D) \\ and Sotiris K. Hadjikakou 1,6,*(D)
}

Citation: Meretoudi, A.; Banti, C.N.; Raptis, P.K.; Papachristodoulou, C.; Kourkoumelis, N.; Ikiades, A.A.; Zoumpoulakis, P.; Mavromoustakos, T.; Hadjikakou, S.K. Silver

Nanoparticles from Oregano Leaves' Extracts as Antimicrobial Components for Non-Infected Hydrogel Contact Lenses. Int. J. Mol. Sci. 2021, 22, 3539. https://doi.org/ 10.3390/ijms22073539

Academic Editor: Iolanda Francolini

Received: 12 March 2021

Accepted: 25 March 2021

Published: 29 March 2021

Publisher's Note: MDPI stays neutral with regard to jurisdictional claims in published maps and institutional affiliations.

Copyright: (c) 2021 by the authors. Licensee MDPI, Basel, Switzerland. This article is an open access article distributed under the terms and conditions of the Creative Commons Attribution (CC BY) license (https:// creativecommons.org/licenses/by/ $4.0 /)$.
1 Inorganic Chemistry Laboratory, Department of Chemistry, University of Ioannina, 45110 Ioannina, Greece; ameretoudi1996@gmail.com (A.M.); panagiwtisraptis93@yahoo.gr (P.K.R.)

2 Department of Physics, University of Ioannina, 45110 Ioannina, Greece; xpapaxri@uoi.gr (C.P.); ikiadis@uoi.gr (A.A.I.)

3 Medical Physics Laboratory, Medical School, University of Ioannina, 45110 Ioannina, Greece; nkourkou@uoi.gr

4 Laboratory of Chemistry, Analysis \& Design of Food Processes, Department of Food Science and Technology, University of West Attica, 11635 Attica, Greece; pzoump@eie.gr

5 Organic Chemistry Laboratory, Department of Chemistry, University of Athens Greece, 15571 Athens, Greece; tmavrom@chem.uoa.gr

6 Institute of Materials Science and Computing, University Research Center of Ioannina (URCI), 45110 Ioannina, Greece

* Correspondence: cbanti@uoi.gr (C.N.B.); shadjika@uoi.gr (S.K.H.); Tel.: +30-26510-08374 (S.K.H.)

Abstract: The oregano leaves' extract (ORLE) was used for the formation of silver nanoparticles (AgNPs(ORLE)). ORLE and AgNPs(ORLE) $(2 \mathrm{mg} / \mathrm{mL})$ were dispersed in polymer hydrogels to give the pHEMA@ORLE_2 and pHEMA@AgNPs(ORLE)_2 using hydroxyethyl-methacrylate (HEMA). The materials were characterized by $X$-ray fluorescence (XRF) spectroscopy, $X$-ray powder diffraction analysis (XRPD), thermogravimetric differential thermal analysis (TG-DTA), derivative thermogravimetry/differential scanning calorimetry (DTG/DSC), ultraviolet (UV-Vis), and attenuated total reflection mode (ATR-FTIR) spectroscopies in solid state and UV-Vis in solution. The crystallite size value, analyzed with XRPD, was determined at $20 \mathrm{~nm}$. The antimicrobial activity of the materials was investigated against Gram-negative bacterial strains Pseudomonas aeruginosa (P. aeruginosa) and Escherichia coli (E. coli). The Gram-positive ones of the genus of Staphylococcus epidermidis (S. epidermidis) and Staphylococcus aureus (S. aureus) are known to be involved in microbial keratitis by the means of inhibitory zone (IZ), minimum inhibitory concentration (MIC), and minimum bactericidal concentration (MBC). The IZs, which developed upon incubation of P. aeruginosa, E. coli, S. epidermidis, and $S$. aureus with paper discs soaked in $2 \mathrm{mg} / \mathrm{mL}$ of AgNPs(ORLE), were $11.7 \pm 0.7,13.5 \pm 1.9$, $12.7 \pm 1.7$, and $14.3 \pm 1.7 \mathrm{~mm}$. When the same dose of ORLE was administrated, the IZs were $10.2 \pm 0.7,9.2 \pm 0.5,9.0 \pm 0.0$, and $9.0 \pm 0.0 \mathrm{~mm}$. The percent of bacterial viability when they were incubated over the polymeric hydrogel discs of pHEMA@AgNPs(ORLE)_2 was interestingly low (66.5, 88.3, 77.7, and 59.6\%, respectively, against of P. aeruginosa, E. coli, S. epidermidis, and S. aureus) and those of pHEMA@ORLE_2 were 89.3, 88.1, 92.8, and 84.6\%, respectively. Consequently, pHEMA@AgNPs(ORLE)_2 could be an efficient candidate toward the development of non-infectious contact lenses.

Keywords: silver nanoparticles; oregano leaves' extract; antimicrobial materials; hydrogels; contact lens

\section{Introduction}

Contact lenses are made of hydrogels such as poly-2-hydroxyethylmethacrylate (pHEMA) [1,2]. The pHEMA is a synthetic biocompatible hydrogel material for contact 
lens' development, which was approved by the Food and Drug Administration (FDA) in 1971 [3]. The advantages of the use of pHEMA in contact lenses arise from its water and oxygen permeability [1,2]. However, bacteria such as Pseudomonas aeruginosa, Escherichia coli, Staphylococcus epidermidis, and Staphylococcus aureus are often colonizing contact lens' materials $[4,5]$. Thus, contact lens may be the etiology of bacterial infections such as Microbial Keratitis (MK). This initiates the research for novel material's' development, which exhibits the benefits of typical contact lenses without the peril for severe bacterial infections. The dispersion of antimicrobial agents leads to loading of antibacterial properties in the polymeric material [6,7]. Silver(I) ions have been pursued as additives to contact lenses for their antimicrobial efficacy [8]. However, the major drawback of the ionic silver usage is the inactivation through complexation with chloride anions of the human fluids and their precipitation. Silver nanoparticles, on the other hand, are a valuable alternative [8]. The silver nanoparticles show efficient antimicrobial property compared to other salts due to their extremely large surface area, which provides better contact between the nanoparticles and the cells of the microorganisms [9].

While essential oils, such as Origanum vulgare, exhibit antibacterial, antifungal, antiviral, anti-inflammatory, and antioxidant properties [10,11], plant extracts are used for chemical synthetic procedure of nanomaterials as reducing or stabilizing agents [12]. The type of the plant extracts affects the characteristics of the produced nanoparticles since different plant extracts contain different concentrations and combinations of organic reducing agents [12]. Thus, AgNPs from ethanolic oregano leaves' extracts exhibit stronger antimicrobial activity against Gram-positive (Staphylococcus aureus, Bacillus subtilis) strains than against Gram-negative (Escherichia coli, Salmonella typhimurium) strains [13]. Moreover, silver nanoparticles from aqueous oregano plant extract have shown antibacterial and antifungal activities against Shigella sonnei, Micrococcus luteus, Escherichia coli, Aspergillus flavus, Alternaria alternate, Paecilomyces variotii, and Phialophora alba [14]. AgNPs from essential oil of oregano possessed antimicrobial activity against $S$. aureus [10].

Aiming for the formation of new, non-infectious materials for sterile antimicrobial contact lenses' development, we report here the synthesis of AgNPs(ORLE) obtained from oregano leaves extract (ORLE). Consequently, they were incorporated in pHEMA hydrogels. The materials pHEMA@ORLE_2 and pHEMA@AgNPs(ORLE)_2 were characterized by XRF, XRPD, TG-DTA, DTG/DSC, UV-Vis, ATR-FTIR, and refractive index in solid state and UV-Vis spectroscopy in solution. The antimicrobial activity of the materials was evaluated against the Gram-negative bacterial strains P. aeruginosa and E. coli and the Gram-positive ones, S. epidermidis and S. aureus, which are involved in microbial contamination of contact lenses, leading to ocular infections.

\section{Results}

\subsection{General Aspects}

In order to evaluate the antimicrobial efficiency of contact lens with antimicrobial components, a solution of AgNPs(ORLE) $(2 \mathrm{mg} / \mathrm{mL}$ ) was dispersed in pHEMA (Scheme 1) during its polymerization procedure. Consequently, the pHEMA@AgNPs(ORLE)_2 was derived. Similarly, oregano leaves' extract (ORLE) was isolated and used for the preparation of pHEMA@ORLE_2. The pHEMA, pHEMA@ORLE_2, and pHEMA@AgNPs(ORLE)_2 discs of 10-mm diameter were cut, cleaned from monomers, and stored either in sterilized $\mathrm{NaCl} 0.9 \% w / w$ solution or they were dried at $50{ }^{\circ} \mathrm{C}$ (Figure S1). 
<smiles>C=C(C)C(=O)OCCO</smiles>

2-hydroxyethyl methacrylate<smiles>C=C(C)C(=O)OCCOC(=O)C(=C)C</smiles>

ethylene glycol dimethacrylate

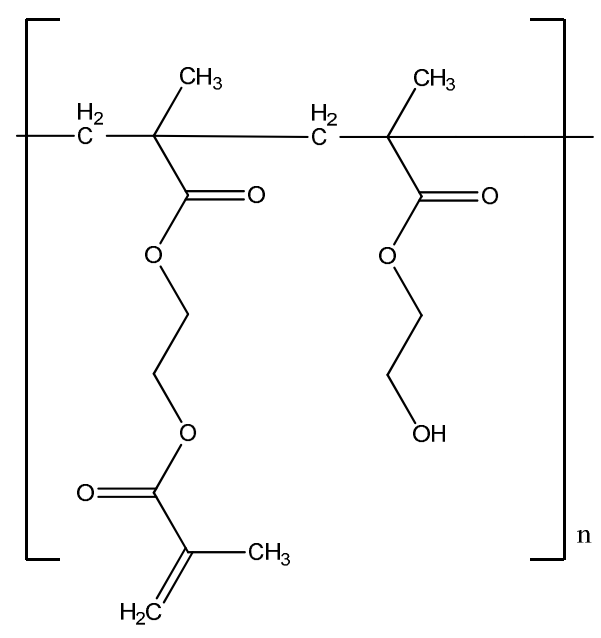

Poly(EDGMA-HEMA)

(pHEMA)

Scheme 1. Preparation reaction of poly-hydroxyethyl-methacrylate. (pHEMA).

\subsection{Solid State}

\subsubsection{Refractive Index}

The refractive indexes of stored discs in saline solution exhibit almost the same refractive index (1.434 (pHEMA), 1.434 (pHEMA@ORLE_2), and 1.433 (pHEMA@AgNPs(ORLE)_2)). These values are in accordance with the corresponding one of the pHEMA@platinumnanoparticles (1.424-1.436) [8] and pHEMA@AGMNA-1 (AGMNA $=\left\{\left[\operatorname{Ag}_{6}\left(\mu_{3}-\mathrm{HMNA}\right)_{4}\left(\mu_{3^{-}}\right.\right.\right.$ MNA $\left.\left.\left.)_{2}\right]^{2-} \cdot\left[\left(\mathrm{Et}_{3} \mathrm{NH}\right)^{+}\right]_{2} \cdot(\mathrm{DMSO})_{2} \cdot\left(\mathrm{H}_{2} \mathrm{O}\right)\right\}\right)(1.436)$ [7], although the ideal hydrogels should have a refractive index value matching the range of 1.372-1.381 [3]. However, the fabricated hydrogel is highly transparent, with refractive indexes ranging from 1.42 to 1.45 in the spectra range from 400 to $800 \mathrm{~nm}[15,16]$.

\subsubsection{X-ray Fluorescence Spectroscopy}

The XRF spectrum of the AgNPs(ORLE) and pHEMA@AgNPs(ORLE)_2 powders confirmed the presence of $\mathrm{Ag}$. Moreover, the $\mathrm{Ag} \mathrm{K} \alpha \mathrm{X}$-ray emission was used for quantitative determination of Ag in the AgNPs(ORLE). The content of silver in AgNPs(ORLE) was determined at $37 \pm 5 \% w / w$. (Figure 1 ). However, the silver content in the case of pHEMA@AgNPs(ORLE)_2 was unable to be determined due to its low quantity, which was close to the limits of the method.

\subsubsection{X-ray Powder Diffraction Analysis (XRPD)}

To perform crystallite size analysis of AgNPs(ORLE) with XRPD (Figure 2), the different contributions to specimen broadening were separated. The observed diffraction profile was the result of the of a specimen profile (f) and the aberrations introduced by the diffractometer. Therefore, the shape of the instrument line profile $(\mathrm{g})$ due to the non-ideal optical contribution of the diffractometer and the wavelength distribution of the radiation should be known. Using a corundum $\left(\mathrm{Al}_{2} \mathrm{O}_{3}\right)$ standard, the $g$ was convoluted with $\mathrm{f}$, in order to obtain a calculated instrument line profile, which was then applied to the measured profile of our sample (h). The pseudo-Voigt shape function was used, and the curve shape parameter, the skewness, and the $\mathrm{k} \alpha_{2}$ contribution were allowed to be refined during the peak fitting. The peak width was defined as the full width at half maximum (FWHM), knowing that the peak width varied inversely with crystallite size. Microstrain broadening analysis was not performed and, therefore, results might be less accurate at larger 2-theta angles. The profiles of the three Bragg peaks at 38.2, 64.5, and 77.5 were calculated and 
the following crystallite sizes were obtained: 210,197 , and $194 \AA$ A. The similar obtained values showed minimal crystalline strain, yielding an average crystallite size value of approximately $20 \mathrm{~nm}$.

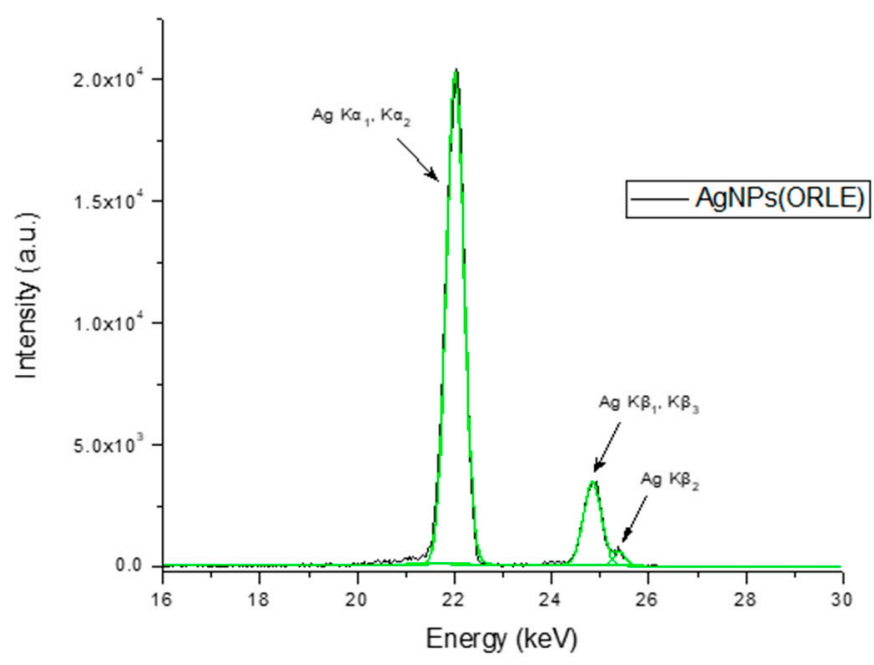

[A]

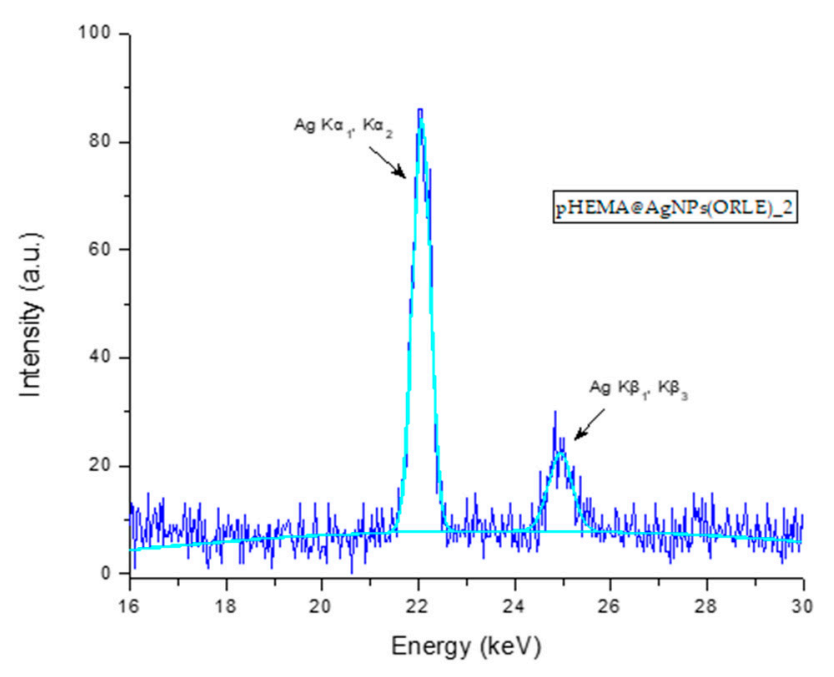

[B]

Figure 1. The Ag K $\alpha$ radiation emitted from AgNPs(ORLE) (A) and pHEMA@AgNPs(ORLE)_2 (B) Oregano leaves extract (ORLE).

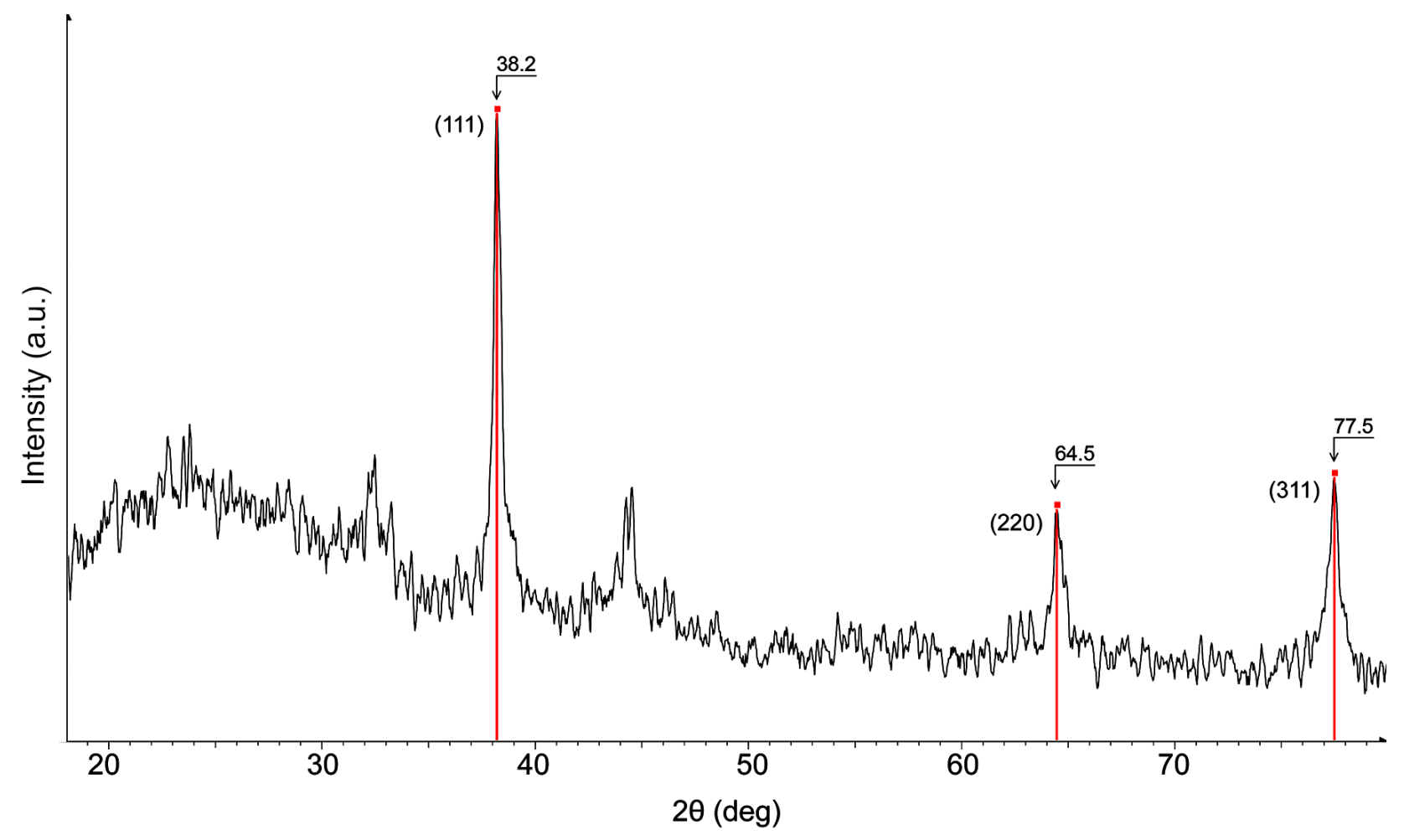

Figure 2. Powder X-ray diagram of sample AgNPs(ORLE) with the characteristic Bragg peaks of Ag nanoparticles.

2.2.4. Thermogravimetric Analysis of AgNPs(ORLE), pHEMA, and pHEMA@AgNPs(ORLE)_2

Differential Scanning Calorimetry (DSC)

In order to clarify whether AgNPs(ORLE) interact with pHEMA in solid state leading to a mixture or a composite material, DSC studies were carried out on the powder of dry pHEMA and pHEMA@AgNPs(ORLE)_2 (Figure 3). An endothermic transition 
at $455.3{ }^{\circ} \mathrm{C}$ in the DSC thermo-diagram of pHEMA@AgNPs(ORLE)_2 was observed at higher temperature at $459.7^{\circ} \mathrm{C}$ in the free pHEMA, suggesting the formation of a composite material rather than a mixture of precursors. The formation of the composite material was further supported by the sharp endothermic transition at $443.8{ }^{\circ} \mathrm{C}$ in the diagram of pHEMA@AgNPs(ORLE)_2, which is absent in the corresponding diagrams of AgNPs(ORLE) and pHEMA, respectively (Figure 3).

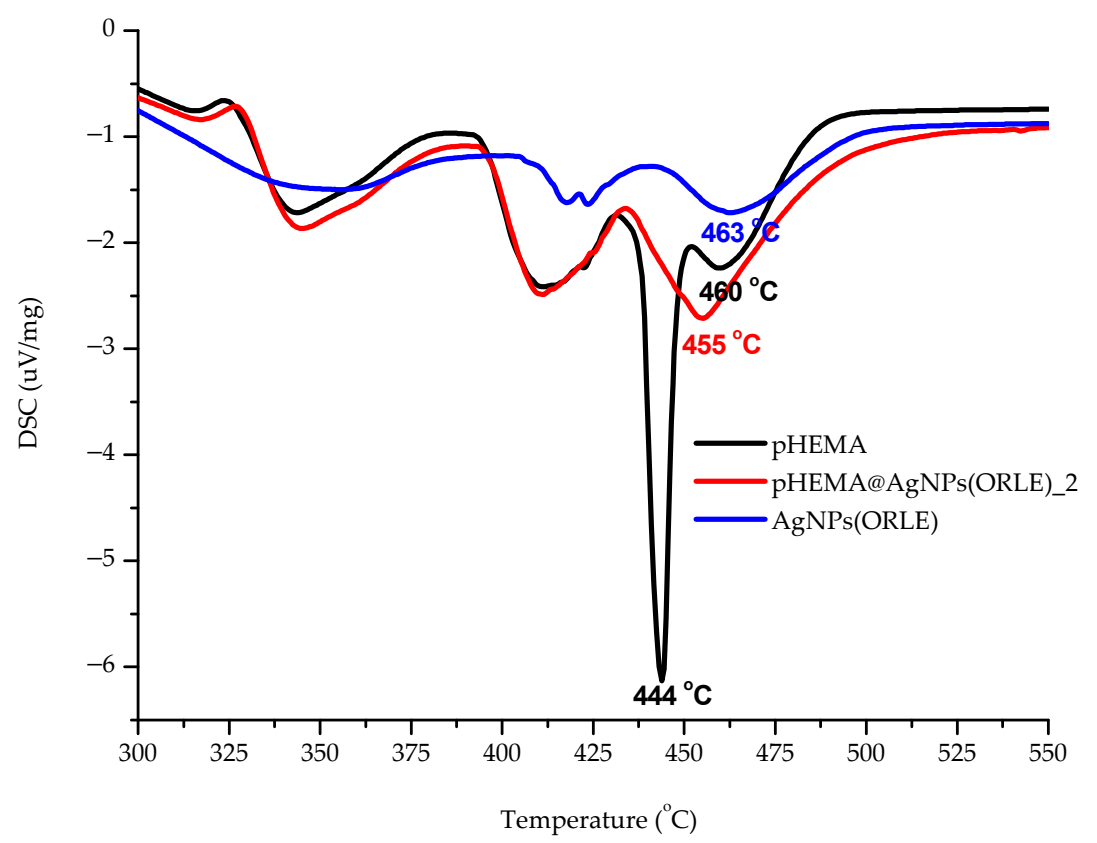

Figure 3. Differential scanning calorimetry (DSC) thermo-diagrams of pHEMA, AgNPs(ORLE), and pHEMA@AgNPs(ORLE)_2.

Thermal Decomposition of AgNPs(ORLE) and The Composite pHEMA@AgNPs(ORLE)_2

TG-DTA analysis was performed under air on the powder of dry AgNPs(ORLE) and pHEMA@AgNPs(ORLE)_2 with increasing the temperature at a rate of $10{ }^{\circ} \mathrm{C} \mathrm{min}-1$ from ambient up to $500^{\circ} \mathrm{C}$ (Figure 4). The composite pHEMA@AgNPs(ORLE)_2 decomposed with five endothermic steps at 50-221, 221-298, 298-376, 376-430 and $430-527^{\circ} \mathrm{C}$ with total mass loss 96.0\%. The AgNPs(ORLE) decomposed with four endothermic steps at 50-218, $218-393,393-424$, and $424-463{ }^{\circ} \mathrm{C}$ with total mass loss of $96.5 \%$ (Figure 4 ).
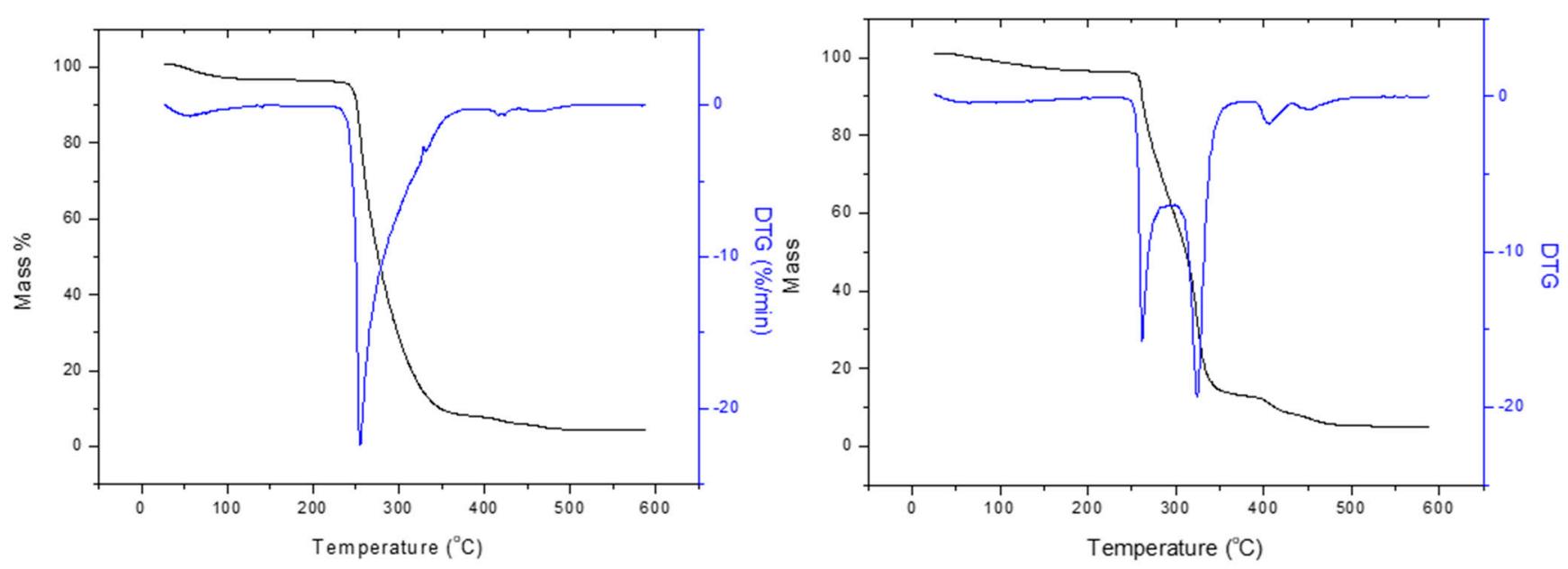

Figure 4. TGA diagrams of AgNPs(ORLE) (left) and pHEMA@AgNPs(ORLE)_2 (right). 


\subsubsection{Ultraviolet-Visible Spectroscopy (UV-Vis)}

Solid State UV-Vis Spectra

The dispersion of the AgNPs(ORLE) in pHEMA within pHEMA@AgNPs(ORLE)_2 was verified by the solid state UV-Vis spectroscopy (Figure 5). The characteristic broad band at $330 \mathrm{~nm}$ in the solid state UV-Vis spectrum of pHEMA@AgNPs(ORLE)_2, which is absent in the corresponding one of free pHEMA, suggested the incorporation of the $\mathrm{AgNPs}(\mathrm{ORLE})$ in it.

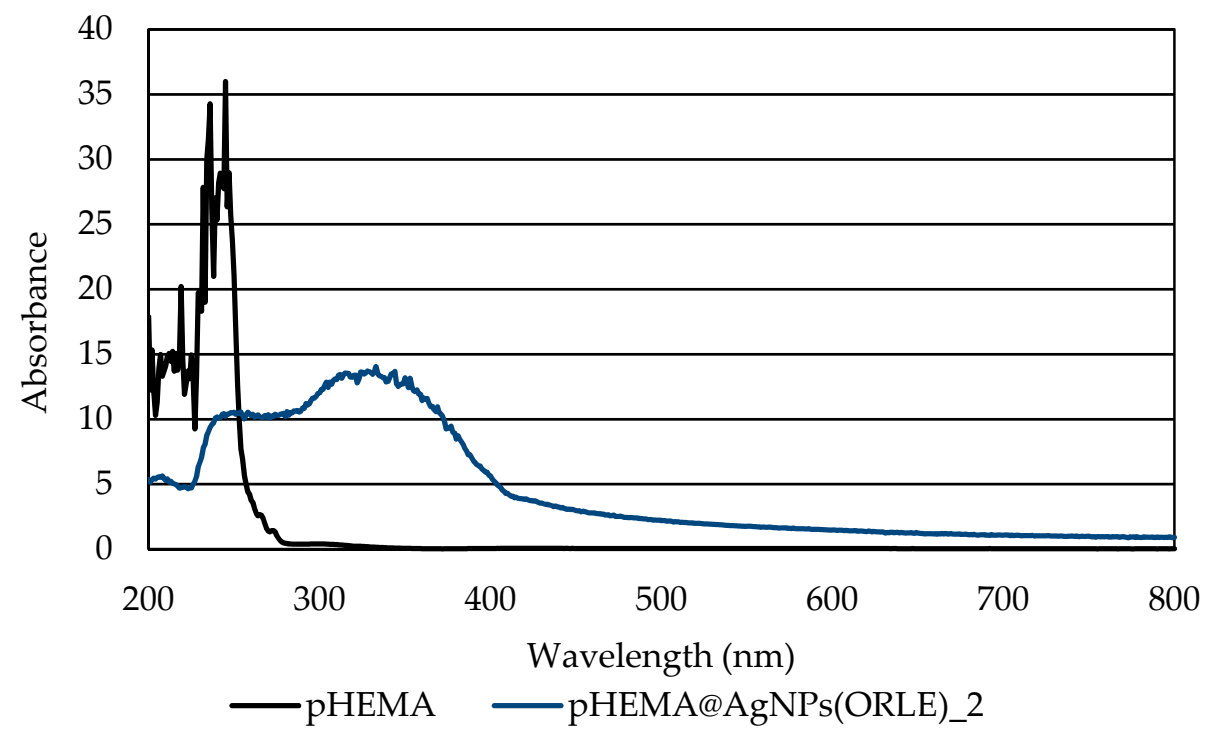

Figure 5. UV solid state of pHEMA and pHEMA@AgNPs(ORLE)_2.

\section{Solution State Spectra}

Since absorption band in UV-Vis spectra of AgNPs between 400-500 $\mathrm{nm}$ has been assigned to the collective resonance of electrons at the surface of the silver nanoparticles, these bands were used for the determination of silver nanoparticles' size $[17,18]$. The UV-Vis spectrum of AgNPs(ORLE) in double distilled (dd) water solution $(0.4 \mathrm{mg} / \mathrm{mL})$ (Figure 6) exhibited a broad band at $479 \mathrm{~nm}$, which correlated to nanoparticles' size of $\sim 65 \mathrm{~nm}$ [19]. It is mentioned here that the size of $20 \mathrm{~nm}$, which was determined by XRPD spectroscopy (see above), refers to crystallite sizes and not to solubilized particles studied here by UV-Vis spectroscopy.

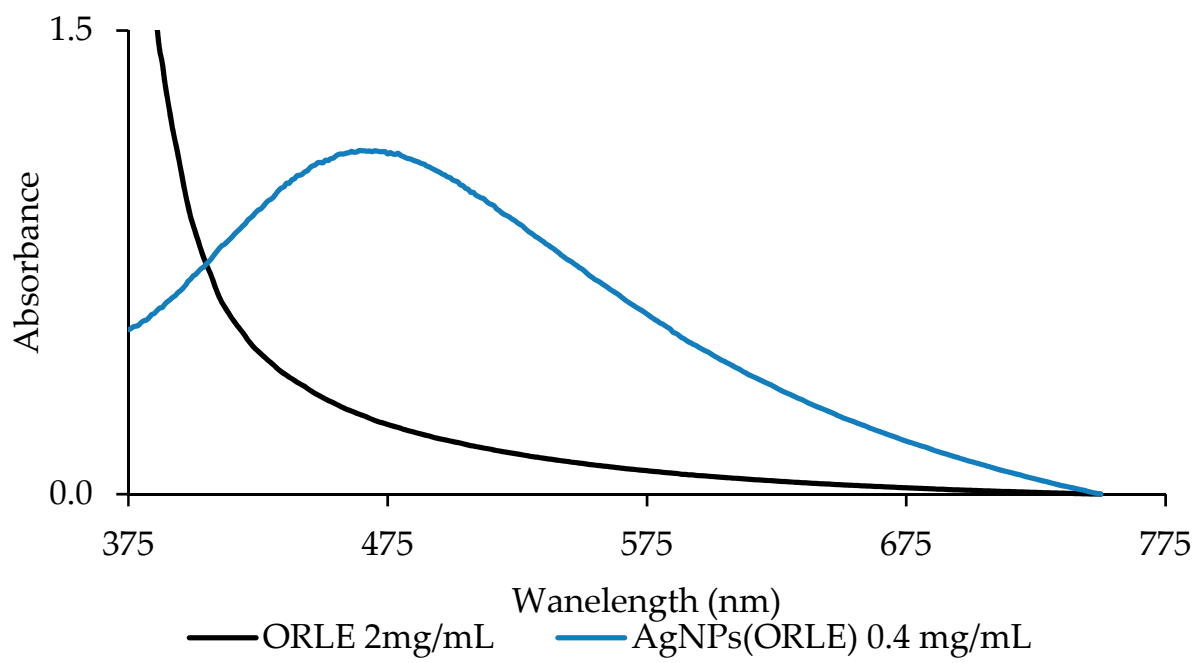

Figure 6. UV-Vis spectrum of AgNPs(ORLE) in double-distilled (dd) water solution. 


\subsection{Antibacterial Activity of ORLE and AgNPs(ORLE)}

\subsubsection{Determination of the Inhibition Zone (IZ) through Agar Disc-Diffusion Method}

The agar disc-diffusion method was employed in order to survey the sensitivity of the microorganism to the antibacterial agent studied here [20]. The diameters of the bacterial growth inhibition zones when P. aeruginosa, E. coli, S. epidermidis, and S. aureus were treated by ORLE and AgNPs(ORLE) with a dose of $2 \mathrm{mg} / \mathrm{mL}$ upon their incubation for $20 \mathrm{~h}$ are summarized in Table 1 (Figure S2). The bacteria showed higher sensitivity to the $\mathrm{AgNPs}(\mathrm{ORLE})$ than ORLE, which rose up to 1.6-fold higher in the case of in the case of $S$. aureus. The microbe strains were classified into three categories according to the size of IZ, caused by an antimicrobial agent in their agar dilution culture: (1) strains, where the agent causes IZ $\geq 17 \mathrm{~mm}$, were susceptible; (ii) those where the agent created IZ between 13 to $16 \mathrm{~mm}(13 \leq \mathrm{IZ} \leq 16 \mathrm{~mm})$ were intermediate; and (3) in those where the agent caused IZ $\leq 12 \mathrm{~mm}$, the microbes were considered as resistant strains [21]. Therefore, the strains studied here (P. aeruginosa, E. coli, S. epidermidis, and S. aureus) responded intermediately to $\operatorname{AgNPs}(\mathrm{ORLE})$, while they were considered as resistant strains toward ORLE [21].

Table 1. Inhibition Zones (IZs). Minimum Inhibitory Concentrations (MICs), Minimum Bactericidal Concentrations (MBCs), Biofilm Elimination Concentrations (BECs) of ORLE, and AgNPs(ORLE) against $P$. aeruginosa, E. coli, S. epidermidis, and S. aureus.

\begin{tabular}{|c|c|c|c|c|}
\hline Material Title & P. aeuroginosa & E. coli & S. epidermidis & S. aureus \\
\hline & \multicolumn{4}{|c|}{ IZ (mm) } \\
\hline $\operatorname{AgNPs}(\mathrm{ORLE}) 2 \mathrm{mg} / \mathrm{mL}$ & $13.1 \pm 1.6$ & $12.3 \pm 0.7$ & $12.7 \pm 1.7$ & $14.8 \pm 1.1$ \\
\hline ORLE $2 \mathrm{mg} / \mathrm{mL}$ & $10.2 \pm 0.7$ & $9.3 \pm 0.5$ & ND & ND \\
\hline pHEMA@AgNPs(ORLE)_2 & $10.3 \pm 0.7$ & ND & $11.0 \pm 1.9$ & $10.3 \pm 0.7$ \\
\hline \multirow[t]{2}{*}{ pHEMA@ORLE_2 } & ND & ND & ND & ND \\
\hline & \multicolumn{4}{|c|}{ Bacteria Viability (\%) } \\
\hline pHEMA@AgNPs(ORLE)_2 & 66.5 & 88.3 & 77.7 & 59.6 \\
\hline \multirow[t]{2}{*}{ pHEMA@ORLE_2 } & 89.3 & 88.1 & 92.8 & 84.6 \\
\hline & \multicolumn{4}{|c|}{$\operatorname{MIC}(\mu \mathrm{g} / \mathrm{mL})$} \\
\hline $\operatorname{AgNPs}(\mathrm{ORLE})$ & $139.5 \pm 17.4$ & $124.3 \pm 12.9$ & $272.2 \pm 14.1$ & $>300$ \\
\hline \multirow[t]{2}{*}{ ORLE } & $>300$ & $>300$ & $>300$ & $>300$ \\
\hline & \multicolumn{4}{|c|}{$\mathrm{MBC}(\mu \mathrm{g} / \mathrm{mL})$} \\
\hline $\operatorname{AgNPs}(\mathrm{ORLE})$ & $135.7 \pm 35.2$ & $>300$ & $>300$ & $>300$ \\
\hline \multirow[t]{2}{*}{ ORLE } & $>300$ & $>300$ & $>300$ & $>300$ \\
\hline & \multicolumn{4}{|c|}{ BEC $(\mu \mathrm{g} / \mathrm{mL})$} \\
\hline $\operatorname{AgNPs}(\mathrm{ORLE})$ & $945 \pm 72$ & - & - & $>1000$ \\
\hline
\end{tabular}

$\mathrm{ND}=$ Not Developed (IZ) was developed. ORLE = oregano leaves extract. IZ= Inhibition Zone. MIC= Minimum Inhibitory Concentration, $\mathrm{MBC}=$ Minimum Bactericidal Concentration, $\mathrm{BEC}=$ Biofilm Elimination Concentrations.

The antimicrobial activity of $\mathrm{AgNPs}(\mathrm{ORLE})$ against the microbes prompted us to load it into pHEMA for the development of new non-infectious contact lens pHEMA@AgNPs (ORLE)_2. The pHEMA@ORLE_2 was also prepared for comparison. The inhibition zones of pHEMA@AgNPs(ORLE)_2 against P. aeruginosa, E. coli, S. epidermidis. and S. aureus microbes suggested mild antimicrobial activity (Table 1, Figure 7). Moreover, no inhibition zones were developed when pHEMA@ORLE_2 or pHEMA was used against all tested strains (Figure S3). Since the agar diffusion test showed that pHEMA@AgNPs(ORLE)_2 discs, with diameter of $10 \mathrm{~mm}$, which contained $2 \mathrm{mg} / \mathrm{mL}$ AgNPs(ORLE), developed shorter IZs against P. aeruginosa, E. coli, S. epidermidis, and S. aureus (10.3 \pm 0.7 , not developed (ND), $11.0 \pm 1.9$, and $10.3 \pm 0.7 \mathrm{~mm}$, respectively) than soaked paper discs, (diameter of $9 \mathrm{~mm})$ with a solution of $\operatorname{AgNPs}(\mathrm{ORLE})(2 \mathrm{mg} / \mathrm{mL})(13.1 \pm 1.6,12.3 \pm 0.7,12.7 \pm 1.7$, 
and $14.8 \pm 1.1 \mathrm{~mm}$, respectively), a minor releasing of the discs' ingredient could be concluded.

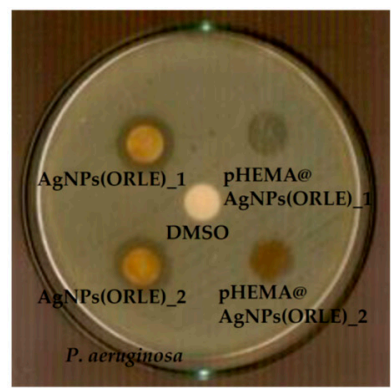

[A]

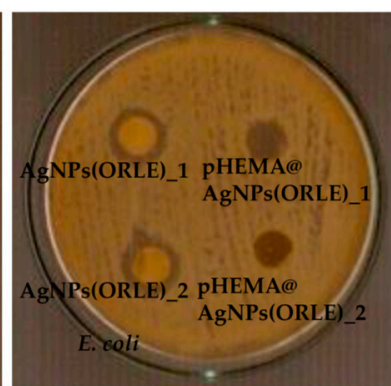

[B]

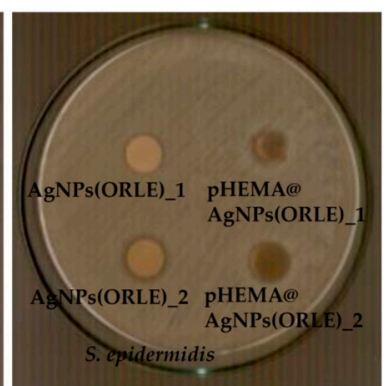

$[\mathrm{C}]$

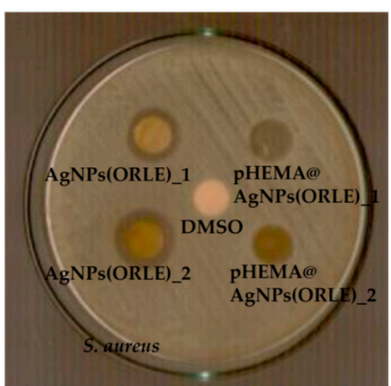

[D]

Figure 7. Inhibition zones of pHEMA and pHEMA@AgNPs(ORLE)_2 against Pseudomonas aeruginosa (P. aeruginosa) (A), Escherichia coli (E. coli) (B), Staphylococcus epidermidis (S. epidermidis) (C), and Staphylococcus aureus (S. aureus) (D).

Thus, pHEMA, pHEMA@ORLE_2, and pHEMA@AgNPs(ORLE)_2 discs were placed in tests tubes that contained $5 \times 10^{5} \mathrm{cfu} / \mathrm{mL}$ of $P$. aeruginosa, E. coli, S. epidermidis, and $S$. aureus microbes. The calculated bacterial\% viability of P. aeruginosa, E. coli, S. epidermidis, and S. aureus upon their incubation with pHEMA@AgNPs(ORLE)_2 discs for $20 \mathrm{~h}$ was 66.5, $88.3,77.7$, and $59.6 \%$, respectively (Figure 8 ). On the contrary, no or meaningless influence in the bacterial viability was observed against these bacterial strains, upon their treatment by discs of pHEMA@ORLE_2 or pure pHEMA (Table 1, Figure 8).

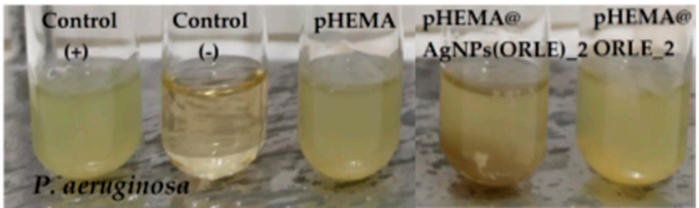

[A]

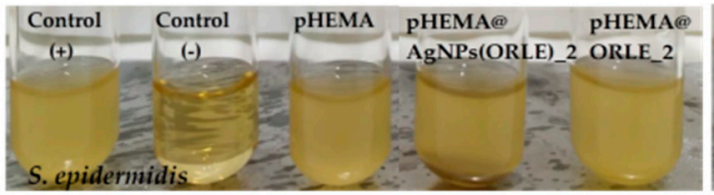

$[\mathrm{C}]$

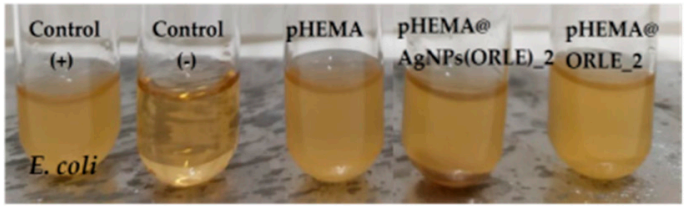

[B]

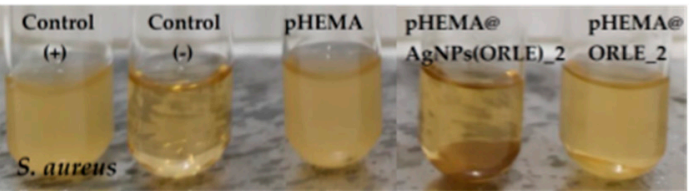

[D]

Figure 8. Bacteria viability of pHEMA, pHEMA@ORLE_2, and pHEMA@AgNPs(ORLE)_2 and against P. aeruginosa (A), E. coli (B), S. epidermidis (C), and S. aureus (D).

\subsubsection{Effects on Biofilm Formation}

The adhesion of bacterial cells to surfaces is the initial stage of the formation of biofilm. Thus, bacterial colonies are attached in a surface and they are protected in a polysaccharides' matrix. The necessity of the surgical removal of the infected tissue, which is then followed in the untreated cases, contains high risk for corneal blindness. The biofilm elimination can be achieved by applying metallodrugs [22].

The removal of biofilm was also assessed using crystal violet assay [23]. The discs of pHEMA@AgNPs(ORLE)_2 eliminated the biofilm of P. aeruginosa by $22 \%$, while no inhibitory activity was observed against the biofilm of S. aureus (Figure S4).

\subsubsection{Minimum Inhibitory (MIC) and Minimum Bactericidal (MBC) Concentrations}

The antimicrobial potency of ORLE and AgNPs(ORLE) against Gram-negative ( $P$. aeruginosa and E. coli) and Gram-positive (S. epidermidis and S. aureus) was evaluated by the 
mean of MIC, which is the lowest concentration needed for the inhibition of the bacterial growth, and the MBC, which is the lowest concentration of an antibacterial agent that can eliminate $99.9 \%$ of the bacterial inoculum $[23,24]$. The MIC and MBC values of ORLE and AgNPs(ORLE) against microbes studied here are summarized in Table 1 (Figures S5-S10). ORLE was inactive against the strains used.

\subsubsection{Effects on Biofilm Formation by AgNPs(ORLE)}

The effect of AgNPs(ORLE) against biofilm formation of P. aeuroginosa and S. aureus was studied by the biofilm elimination concentration (BEC) using crystal violet assay [7,23]. The BEC was defined as the concentration required to achieve at least a $99.9 \%$ reduction in the viability of biofilm bacteria. The composite material inhibited the biofilm formation, reducing $100 \%$ of its biomass, at $945 \pm 72 \mu \mathrm{g} / \mathrm{mL}$, against $P$. aeuroginosa, while it was not determined for $S$ aureus for concentrations up to $1000 \mu \mathrm{g} / \mathrm{mL}$ (Figure S11). The BEC value of ciprofloxacin, a known antibiotic use for the bacterial keratitis, was $221 \mu \mathrm{g} / \mathrm{mL}$ toward P. aeuroginosa [6].

\subsubsection{In Vitro Toxicity against Normal Human Corneal Epithelial Cells (HCECs)}

The in vitro toxicity of ORLE and AgNPs(ORLE) was evaluated against normal human corneal epithelial cells (HCECs) after their incubation for a period of $48 \mathrm{~h}$. The Inhibitory Concentration of the $50 \%$ of the cells $\left(\mathrm{IC}_{50}\right)$ values for ORLE and AgNPs(ORLE) were higher than $200 \mu \mathrm{g} / \mathrm{mL}$, suggesting low toxicity toward normal cells. The cell viability of HCECs upon their incubation with discs of pHEMA@ORLE_2 and pHEMA@AgNPs(ORLE)_2 was decreased at $90.0 \pm 9.5$ and $54.9 \pm 7.1 \%$, respectively, in respect of the cells incubated with pHEMA discs.

\subsubsection{In Vivo Toxicity Evaluation by Brine Shrimp Artemia Salina}

Artemia salina is a zooplanktonic crustacean $[25,26]$ and the nauplii of the brine shrimp are considered as a simple and suitable model system for acute toxicity tests [26,27]. The assay can be correlated with the toxicity data of rodents and humans and shows a good correlation with cytotoxicity tests, making these measurements suitable as preliminary results $[26,28,29]$. The lethality was noted in terms of deaths of larvae.

The (\%) mortality of Artemia salina larvae upon their incubation with ORLE and AgNPs(ORLE) at the concentrations of 150-300 $\mu \mathrm{g} / \mathrm{mL}$ are summarized in Table 2. The mortality rate (\%) of brine shrimp larvae incubated with ORLE and AgNPs(ORLE) rose from 4.0 and $7.1 \%(150 \mu \mathrm{g} / \mathrm{mL})$ up to $78 \%$ at $300 \mu \mathrm{g} / \mathrm{mL}$ for both ORLE and AgNPs(ORLE) (Table 2). No mortality of brine shrimp larvae was found upon incubation of pHEMA, pHEMA@ORLE_2, and pHEMA@AgNPs(ORLE)_2 for 24 h, indicating their non-toxic behavior.

Table 2. Percent mortality of Artemia salina larvae in increasing concentrations of solutions with ORLE and AgNPs(ORLE).

\begin{tabular}{ccc}
\hline Tested Concentration $(\mu \mathrm{g} / \mathrm{mL})$ & \% Mortality \\
\hline & ORLE & AgNPs(ORLE) \\
\hline 150 & $4.0 \pm 3.3$ & $7.1 \pm 3.4$ \\
\hline 200 & $33.9 \pm 9.9$ & $36.6 \pm 11.6$ \\
\hline 250 & $34.5 \pm 14.1$ & $26.4 \pm 11.4$ \\
\hline 300 & $78.4 \pm 13.4$ & $78.8 \pm 23.1$ \\
\hline
\end{tabular}

\section{Materials and Methods}

\subsection{Materials and Instruments}

All solvents used were of reagent grade. Tryptone and soy peptone were purchased from Biolife, Milano, Italy. Agar was purchased from Sigma-Aldrich St. Louis, MO, USA 
product of Spain. Sodium cloride, $\mathrm{D}(+)-$ Glucose, and di potassium hydrogen phosphate trihydrate were purchased from Merck, Darmstadt, Germany. DMSO was purchased from Riedel-de Haen (Seelze, Germany). Melting points were measured in open tubes with a Stuart Scientific apparatus and are uncorrected. A UV-1600 PC series spectrophotometer of VWR international GmbH, Darmstadt, Germany was used to obtain electronic absorption spectra. ATR-FTIR spectra in the region of $4000-370 \mathrm{~cm}^{-1}$ were obtained with a Cary 670 FTIR spectrometer, Agilent Technologies Agilent Technologies. XRF measurement was carried out using an Am-241 radio isotopic source (exciting radiation $59.5 \mathrm{keV}$ ).

\subsection{Preparation of ORLE and $A g N P S(O R L E)$}

Dry oregano leaves $(4 \mathrm{~g})$ were refluxed using a Soxhlet apparatus with $50 \mathrm{~mL}$ dd water for $3 \mathrm{~h}$. The ORLE extract was then obtained with filtration of the initial extract using Whatman No. 1 filter paper. In a beaker $(250 \mathrm{~mL}), 10 \mathrm{~mL}$ ORLE and $170 \mathrm{mg} \mathrm{AgNO}_{3}$ $(1 \mathrm{mmol})$ were added. The beaker was placed in a microwave oven $(700 \mathrm{~W})$ for $2 \mathrm{~min}$. Consequently, the solution was placed in the sonicator (ultrasonic) for $10 \mathrm{~min}$. The solution was centrifugal at $6000 \mathrm{rpm}$ for $20 \mathrm{~min}$ and the AgNPs(ORLE) were collected.

ORLE: yield $0.2 \mathrm{~g}$, brown powder, melting point: $180-184^{\circ} \mathrm{C}$ (change of color); ATR-IR $\left(\mathrm{cm}^{-1}\right)$ : $3855 \mathrm{w}, 3265 \mathrm{w}, 1590 \mathrm{~m}, 1427,1266 \mathrm{w}, 1079,1026,989,730,685,605,564,526,505$, 476, 455, and 426; UV-Vis $\left(\mathrm{ddH}_{2} \mathrm{O}\right): \lambda \max =356 \mathrm{~nm}$.

$\mathrm{AgNPs}(\mathrm{ORLE})$ : yield $0.0232 \mathrm{~g}$; content of $\mathrm{Ag}$ in $\mathrm{AgNPs}(\mathrm{ORLE}): 37 \pm 5 \% w / w$; melting point: $>250{ }^{\circ} \mathrm{C}$ IR $\left(\mathrm{cm}^{-1}\right): 3135 \mathrm{w}, 2641,2324 \mathrm{w}, 1699 \mathrm{w}, 1594 \mathrm{~m}, 1504 \mathrm{w}, 1442 \mathrm{w}, 1225,1145$, 1011, 807 w, 766 w, 7368 w, 692 w, 664 w, 630 w, 595 w, 570 w, 543 w, 509 w, 487, 473 w, 448, $431 \mathrm{~s}$, and $410 \mathrm{~s} ; \mathrm{UV}-\mathrm{Vis}\left(\mathrm{ddH}_{2} \mathrm{O}\right): \lambda \max =479 \mathrm{~nm}$.

\subsection{Synthesis of $p H E M A @ O R L E \_2$ and $p H E M A @ A g N P s(O R L E) \_2$}

Hydrogels of ORLE or AgNPs(ORLE) dispersed in pHEMA were obtained as follows: $2.7 \mathrm{~mL}$ of HEMA were mixed with $2 \mathrm{~mL}$ of double-distilled water (ddw), which contained ORLE or AgNPs(ORLE) $(2 \mathrm{mg} / \mathrm{mL}$ ) and $10 \mu \mathrm{L}$ of ethyleneglycol dimethacrylate (EGDMA). The solution was then degassed by bubbling with nitrogen for $15 \mathrm{~min}$. Trimethylbenzoyldiphenyl-phosphineoxide (TPO) initiator $(6 \mathrm{mg})$ was added to the solution and mixed for $5 \mathrm{~min}$ at $800 \mathrm{rpm}$. The solution was poured into the mold and was then placed under a UV mercury lamp $(\lambda \max =280 \mathrm{~nm}), 15$ watts, for photopolymerization for $40 \mathrm{~min}$. Unreacted monomers were removed by immersing the gel in water for $15 \mathrm{~min}$. Discs with 10-mm diameter were cut and were washed by immersion in water, $\mathrm{NaCl} 0.9 \%$, and $\mathrm{HCl} 0.1 \mathrm{M}$, and again in water. The discs were then dried at $40{ }^{\circ} \mathrm{C}$ until no weight change would occur. The yield of dry pHEMA, pHEMA@ORLE_2, and pHEMA@AgNPs(ORLE)_2 was 1.669 and $1.683 \mathrm{~g}$, respectively.

The pHEMA@ORLE_2: light-brown color; IR $\left(\mathrm{cm}^{-1}\right)$ : $624 \mathrm{w}, 480 \mathrm{w}, 428 \mathrm{w}, \mathrm{UV}-\mathrm{Vis}$ (solid state): $\lambda \max =237 \mathrm{~nm}$

The pHEMA@AgNPs(ORLE)_2: dark-brown color; Ag content in pHEMA@AgNPs (ORLE): $0.21 \pm 0.04 \% w / w$; IR $\left(\mathrm{cm}^{-1}\right) 624 \mathrm{w}, 511 \mathrm{~m}, 480 \mathrm{w}, 424 \mathrm{w}$; UV-Vis (solid phase): $\lambda \max =332 \mathrm{~nm}$.

\subsection{Refractive Indexes}

The values of refractive indexes of the lenses were measured with an Abbe refractometer (NAR-1T, Atago Co., Ltd., Tokyo, Japan) at $24^{\circ} \mathrm{C}$.

\subsection{X-ray Fluorescence Spectroscopy}

XRF measurement was carried out using an Am-241 radioisotopic source (exciting radiation $59.5 \mathrm{keV})$. For the detection of $\mathrm{X}$-ray fluorescence, a $\mathrm{Si}(\mathrm{Li})$ detector was used. The measuring time was chosen so as to collect $\sim 2000$ data on the weaker K $\alpha$ peak. 


\subsection{X-ray Powder Diffraction (XRPD)}

The study of the samples by using the X-ray powder diffraction was accomplished by a diffraction meter D8 AdvanceBruker, department of Physics, University of Ioannina. Radiation $\mathrm{CuKa}(40 \mathrm{kV}, 40 \mathrm{~mA}, \lambda \mathrm{K} \alpha)$ and the monochromator system of diffracted beam were used. The $\mathrm{X}$-ray powder diffraction patterns were measured in the area of $2 \theta$ angles between $2^{\circ}$ and $80^{\circ}$, using a rotation step $0.02^{\circ}$ and time of $2 \mathrm{sec}$ per step. All samples measured with the above diffraction meter were in fine-grained powder form.

\subsection{Thermogravimetric Differential Thermal Analysis (TG-DTA), Differential Scanning Calorimetry (DTG/DSC)}

For the DTA/TG measurements, a DTG/TG NETZSCH STA 449C was used. For the measurements, the samples were placed inside a platinum capsule on one side of the thermal scale while on the other side a-alumina was used as reference sample. The speed of temperature increase was $10^{\circ} \mathrm{C} / \mathrm{min}$ at a temperature range of $25-500{ }^{\circ} \mathrm{C}$ and the measurements took place in the air. All the measured samples were in fine-grained powder form.

\subsection{Bacterial Strains}

The bacterial strains of P. aeruginosa (PAO1), Escherichia coli Dh5a (E. coli), S. aureus $\left(\right.$ ATCC $^{\circledR} 25923^{\mathrm{TM}}$ ), and S. epidermidis $\left(\mathrm{ATCC}^{\circledR} 14990^{\mathrm{TM}}\right.$ ) were adopted in the experiments. The bacterial strain P. aeruginosa PAO1 was kindly offered from Prof. A. Koukou (Laboratory of Biochemistry, University of Ioannina-Greece). The biological experiments were performed in triplicates. The values were evaluated by the statistical analysis software package included in the MS Office excel.

\subsection{Effects on the Growth of Microbial Strains}

The procedure was performed as previously reported $[6,7,23]$. Briefly, bacterial strains plated onto trypticase soy agar were incubated at $37^{\circ} \mathrm{C}$ for $18-24 \mathrm{~h}$. Three to five isolated colonies of the same morphological appearance were selected from a fresh agar plate using a sterile loop and transferred into a tube containing $2 \mathrm{~mL}$ of sterile saline solution. The optical density at $620 \mathrm{~nm}$ was adjusted to 0.1 , which corresponded to $10^{8} \mathrm{cfu} / \mathrm{mL}[6,7,23]$.

For the evaluation of MIC, the inoculum size for broth dilution was $5 \times 10^{5} \mathrm{cfu} / \mathrm{mL}$. The culture solution was treated with ORLE and AgNPs(ORLE) $(20-300 \mu \mathrm{g} / \mathrm{mL})$.

For the evaluation of $\mathrm{MBC}$, the bacteria were initially cultivated in the presence of ORLE and AgNPs(ORLE) in broth culture for $20 \mathrm{~h}$. The MBC values were determined in duplicate, by subculturing $4 \mu \mathrm{L}$ of the broth an agar plate $[6,7,23]$.

In order to evaluate the viability of microbes on pHEMA, pHEMA@ORLE_2, and pHEMA@AgNPs(ORLE)_2, discs of the materials were placed in the test tubes, which contained $5 \times 10^{5} \mathrm{cfu} / \mathrm{mL}$ of $P$. aeruginosa, E. coli, S. epidermidis, and S. aureus microbes $[6,7,23]$. The optical densities of the supernatant solutions were then measured to give the $\%$ viability of microbes after incubation for $18-24 \mathrm{~h}[6,7,23]$.

\subsection{Removal of Biofilm, Using Crystal Violet Assay}

Bacteria with a density of $1.3 \times 10^{6} \mathrm{cfu} / \mathrm{mL}$ were inoculated into Luria-Bertani agar (LB agar) medium for $P$. aeruginosa or tryptic soy broth for $S$. aureus (total volume $=1500 \mu \mathrm{L}$ ) and cultured for $20 \mathrm{~h}$ at $37^{\circ} \mathrm{C}$. Afterwards, the content of each tube was carefully removed, the tubes were washed with $1 \mathrm{~mL} 0.9 \%$ saline dilution, and $2 \mathrm{~mL}$ of broth were added. The negative control contained only broth. Then, the bacteria were incubated with ORLE, AgNPs(ORLE), pHEMA, pHEMA@ORLE_2, and pHEMA@AgNPs(ORLE)_2 for $20 \mathrm{~h}$ at $37^{\circ} \mathrm{C}$. The content of each tube was aspirated and was washed three times with $1 \mathrm{~mL}$ methanol and $2 \mathrm{~mL} 0.9 \%$ saline and left to dry. Then, the tubes were stained for $15 \mathrm{~min}$ with crystal violet solution $(0.1 \% w / v)$. Excess stain was rinsed off with $1 \mathrm{~mL}$ methanol and $2 \mathrm{~mL} 0.9 \%$ saline solution and, afterwards, $3 \mathrm{~mL} 0.9 \%$ saline solution. The tubes were left to dry for $24 \mathrm{~h}$ and the bounded crystal violet was released by adding $30 \%$ glacial acetic 
acid. The optical density of the solution yielded was then measured at $550 \mathrm{~nm}$, to give the biofilm biomass $[6,7,23]$.

\subsection{Determination of the Inhibition Zone (IZ)}

The procedure was performed as previously reported [6,7,23]. Agar plates were inoculated with a standardized inoculum $\left(10^{8} \mathrm{cfu} / \mathrm{mL}\right)$ of the microorganisms. Discs of pHEMA or pHEMA@ORLE_2 and pHEMA@AgNPs(ORLE)_2 with 10-mm diameter or ORLE, AgNPs(ORLE) were placed on the agar surface and the Petri plates were incubated for $20 \mathrm{~h}$.

\subsection{Sulforhodamine B Assay}

Initially, the HCECs were seeded in a 24-well plate in a density of $7.5 \times 10^{4}$ cells. After $24 \mathrm{~h}$ of cell incubation, ORLE, AgNPs(ORLE), the discs of pHEMA, pHEMA@ORLE_2, and pHEMA@AgNPs(ORLE)_2 were added in the wells. After 24-h incubation of HCECs with the discs, the discs were removed, the culture medium was aspirated, and the cells were fixed with $300 \mu \mathrm{L}$ of $10 \%$ cold trichloroacetic acid (TCA). The plate was left for $30 \mathrm{~min}$ at $4{ }^{\circ} \mathrm{C}$, washed five times with deionized water, and left to dry at room temperature for at least $24 \mathrm{~h}$. Subsequently, $300 \mu \mathrm{L}$ of $0.4 \%(w / v)$ sulforhodamine B (SRB) (Sigma) in $1 \%$ acetic acid solution was added to each well and left at room temperature for $20 \mathrm{~min}$. SRB was removed, and the plate was washed five times with $1 \%$ acetic acid before air drying. Bound SRB was solubilized with $1 \mathrm{~mL}$ of $10 \mathrm{mM}$ unbuffered Tris-base solution. Absorbance was read in a 24-well plate reader at $540 \mathrm{~nm}[6,7,23]$.

\subsection{Evaluation of Toxicity with Brine Shrimp Assay}

Brine shrimp assay was performed by a method previously described $[3,7,26]$. One-g cysts were initially hydrated in freshwater for one hour in a separating funnel or coneshaped container. Seawater was prepared by dissolving $17 \mathrm{~g}$ of sea salt in $500 \mathrm{~mL}$ of distilled water $[7,26,30]$. The container was facilitated with good aeration for $48 \mathrm{~h}$ at room temperature and under continuous illumination. After hatching, nauplii released from the eggshells were collected at the bright side of the cone (near the light source) by using a micropipette. The larvae were isolated from the eggs by aliquoting them in a small beaker containing $\mathrm{NaCl} 0.9 \%[7,26,30]$. An aliquot $(0.1 \mathrm{~mL})$ containing about 6 to 10 nauplii was introduced to each well of a 24-well plate and ORLE, AgNPs(ORLE), or one disc of pHEMA or pHEMA@ORLE_2 and pHEMA@AgNPs(ORLE)_2 were added in each well. The final volume of each well was $1 \mathrm{~mL}$ with $\mathrm{NaCl} 0.9 \%$. The brine shrimps were observed at the interval time of $24 \mathrm{~h}$, using a stereoscope. Larvae were considered dead if they did not exhibit any internal or external movement in $10 \mathrm{~s}$ of observation. Each experiment was repeated three times.

\section{Conclusions}

This work aimed for the development of sterilized and non-infectious contact lens. For this purpose, oregano leaves' extract (ORLE) was used for the formation of silver nanoparticles AgNPs(ORLE). AgNPs(ORLE) is an efficient disinfectant. The microbial strains P. aeruginosa, E. coli, S. epidermidis, and S. aureus involved in microbial keratitis responded intermediately to $\mathrm{AgNPs}(\mathrm{ORLE})$. The dispersion of $\mathrm{AgNPs}(\mathrm{ORLE})$ in pHEMA resulted in the composite material pHEMA@AgNPs(ORLE)_2. The percent of bacterial viability of $P$. aeruginosa, E. coli, S. epidermidis, and S. aureus upon their incubation with pHEMA@AgNPs(ORLE)_2 discs decreased by 33.5, 11.7, 22.3, and 40.4\%, respectively, while it was also preventing the formation of biofilm on their surface. The cell viability of HCECA upon their incubation with pHEMA@AgNPs(ORLE)_2 discs for $48 \mathrm{~h}$ decreased by $54.9 \pm 7.1 \%$. No mortality of brine shrimp larvae was found upon their incubation with pHEMA@AgNPs(ORLE)_2 for $24 \mathrm{~h}$, indicating non-toxic in vivo behavior. Thus, pHEMA@AgNPs(ORLE)_2 is an effective candidate for the development of new noninfectious contact lens. 
Supplementary Materials: The following are available online at https:/ /www.mdpi.com/article/10 .3390/ijms22073539/s1. Figure S1. Dry discs of hydrogels pHEMA@ORLE_2 (left) and pHEMA@ AgNPs(ORLE)_2 (right). Figure S2. Bacterial growth inhibition zones developed in P. aeruginosa (A), E. coli (B), S. epidermidis (C), and S. aureus (D) by ORLE and AgNPs(ORLE) with doses of 1 or $2 \mathrm{mg} / \mathrm{mL}$ upon their incubation for $20 \mathrm{~h}$. Figure S3. Bacterial growth inhibition zones developed in P. aeruginosa (A), E. coli (B), S. epidermidis (C), and S. aureus (D) by ORLE and pHEMA@ORLE with doses of 1 or $2 \mathrm{mg} / \mathrm{mL}$ upon their incubation for $20 \mathrm{~h}$. Figure S4. Removal of preformed biofilm of $P$. aeruginosa (A) and S. aureus (B) caused pHEMA, pHEMA@ORLE_2, and pHEMA@AgNPs(ORLE)_2 discs. Figure S5. Minimum inhibitory concentration of ORLE (A) and AgNPs(ORLE) (B) against $P$. aeruginosa. Figure S6. minimum inhibitory concentration of ORLE (A) and AgNPs(ORLE) (B) against E. coli. Figure S7. Minimum inhibitory concentration of ORLE (A) and AgNPs(ORLE) (B) against $S$. epidermidis. Figure S8. Minimum inhibitory concentration of ORLE (A) and AgNPs(ORLE) (B) against S. aureus. Figure S9. Minimum bactericidal concentration of AgNPs(OLRE) against $P$. aeruginosa (A), E. coli (B), S. epidermidis (C), and S. aureus (D). Figure S10. Minimum bactericidal concentration of ORLE against P. aeruginosa (A), E. coli (B), S. epidermidis (C), and S. aureus (D). Figure S11. The biofilm growth of P. aeruginosa (A) and S. aureus (B), under increasing concentrations of AgNPs(ORLE) stained by crystal violet.

Author Contributions: Conceptualization, S.K.H.; investigation, A.M., P.K.R., C.N.B., N.K., C.P., A.A.I., P.Z., and T.M.; methodology, C.N.B. and S.K.H.; supervision, S.K.H.; validation, S.K.H.; writing-original draft, C.N.B. and S.K.H.; writing-review and editing, C.N.B. and S.K.H. All authors have read and agreed to the published version of the manuscript.

Funding: This research was co-financially supported by the European Union and Greek national funds through the Operational Program Competitiveness, Entrepreneurship and Innovation, under the call RESEARCH-CREATE-INNOVATE (project code: T1EDK-02990).

Institutional Review Board Statement: Not applicable.

Informed Consent Statement: Informed consent was obtained from all subjects involved in the study.

Acknowledgments: (1) The International Graduate Program in "Biological Inorganic Chemistry", which operates at the University of Ioannina within the collaboration of the Departments of Chemistry of the Universities of Ioannina, Athens, Thessaloniki, Patras, Crete, and the Department of Chemistry of the University of Cyprus (http://bic.chem.uoi.gr/BIC-En/index-en.html). (2) This research has been co-financed by the European Union and Greek national funds through the Operational Program Competitiveness, Entrepreneurship and Innovation, under the call RESEARCH—CREATEINNOVATE (project code: T1EDK-02990).

Conflicts of Interest: The authors declare no conflict of interest.

\section{Abbreviations}

$\begin{array}{ll}\text { ATR-FT-IR } & \text { Attenuated Total Reflection mode } \\ \text { BEC } & \text { Biofilm Elimination Concentration } \\ \text { DTG/DSC } & \text { Differential Scanning Calorimetry } \\ \text { E. coli } & \text { Escherichia coli } \\ \text { FWHM } & \text { Full Width at Half Maximum } \\ \text { HCEC } & \text { Normal Human Corneal Epithelial Cells } \\ \text { IZ } & \text { Inhibitory Zone } \\ \text { MBC } & \text { Minimum Bactericidal Concentration } \\ \text { MIC } & \text { Minimum Inhibitory Concentration } \\ \text { MK } & \text { Microbial Keratitis } \\ \text { P. aeruginosa } & \text { Pseudomonas aeruginosa } \\ \text { pHEMA } & \text { poly-2-hydroxyethylmethacrylate } \\ \text { S. aureus } & \text { Staphylococcus aureus } \\ \text { S. epidermidis } & \text { Staphylococcus epidermidis } \\ \text { TD-DTA } & \text { Thermogravimetric Differential Thermal Analysis } \\ \text { UV-Vis } & \text { Ultra violet } \\ \text { XRF } & \text { X-ray fluorescence spectroscopy } \\ \text { XRPD } & \text { X-ray powder diffraction analysis } \\ & \end{array}$




\section{References}

1. Musgrave, C.S.A.; Fang, F. Contact Lens Materials: A Materials Science Perspective. Materials 2019, 12, 261. [CrossRef]

2. Wichterle, O.; Lim, D. Hydrophilic Gels for Biological Use. Nature 1960, 185, 117-118. [CrossRef]

3. Caló, E.; Khutoryanskiy, V.V. Biomedical applications of hydrogels: A review of patents and commercial products. Eur. Polym. J. 2015, 65, 252-267. [CrossRef]

4. Schaefer, F.; Bruttin, O.; Zografos, L.; Guex-Crosier, Y. Bacterial keratitis: A prospective clinical and microbiological study. Br. J. Ophthalmol. 2001, 85, 842-847. [CrossRef] [PubMed]

5. Stapleton, F.; Carnt, N. Contact lens-related microbial keratitis: How have epidemiology and genetics helped us with pathogenesis and prophylaxis. Eye 2012, 26, 185-193. [CrossRef]

6. Milionis, I.; Banti, C.B.; Sainis, I.; Raptopoulou, C.P.; Psycharis, V.; Kourkoumelis, N.; Hadjikakou, S.K. Silver ciprofloxacin (CIPAG): A successful combination of chemically modified antibiotic in inorganic-organic hybrid. J. Biol. Inorg. Chem. 2018, 23, 705-723. [CrossRef] [PubMed]

7. Rossos, A.K.; Banti, C.N.; Kalampounias, A.; Papachristodoulou, C.; Kordatos, K.; Zoumpoulakis, P.; Mavromoustakos, T.; Kourkoumelis, N.; Hadjikakou, S.K. pHEMA@AGMNA-1: A novel material for the development of antibacterial contact lens. Mater. Sci. Eng. C 2020, 111, 110770. [CrossRef]

8. Xiao, A.; Dhand, C.; Leung, C.M.; Beuerman, R.W.; Ramakrishna, S.; Lakshminarayanan, R. Strategies to Design Antimicrobial Contact Lenses and Contact Lens Cases. J. Mater. Chem. B 2018, 6, 2171-2186. [CrossRef]

9. Rai, M.; Yadav, A.; Gade, A. Silver nanoparticles as a new generation of antimicrobials. Biotechnol. Adv. 2009, 27, 76-83. [CrossRef]

10. Maciel, M.V.D.O.B.; da Rosa Almeida, A.; Machado, M.H.; Elias, W.C.; da Rosa, C.G.; Teixeira, G.L.; Noronha, C.M.; Bertoldi, F.C.; Nunes, M.R.; de Armas, R.D.; et al. Green synthesis, characteristics and antimicrobial activity of silver nanoparticles mediated by essential oils as reducing agents, Biocatal. Agric. Biotechnol. 2020, 28, 101746.

11. Rodriguez-Garcia, I.; Silva-Espinoza, B.A.; Ortega-Ramirez, L.A.; Leyva, J.M.; Siddiqui, M.W.; Cruz-Valenzuela, M.R.; GonzalezAguilar, G.A.; Ayala-Zavala, J.F. Oregano Essential Oil as an Antimicrobial and Antioxidant Additive in Food Products. Crit. Rev. Food Sci. Nutr. 2016, 56, 1717-1727. [CrossRef] [PubMed]

12. Rahimi-Nasrabadi, M.; Mahdi Pourmortazavi, S.; Ataollah Sadat Shandiz, S.; Ahmadi, F.; Batooli, H. Green synthesis of silver nanoparticles using Eucalyptus leucoxylon leaves extract and evaluating the antioxidant activities of extract. Nat. Prod. Res. 2014, 28, 1964-1969. [CrossRef] [PubMed]

13. Hambardzumyan, S.; Sahakyan, N.; Petrosyan, M.; Jawad Nasim, M.; Jacob, C.; Trchounian, A. Origanum vulgare L. extractmediated synthesis of silver nanoparticles, their characterization and antibacterial activities. AMB Express 2020, 10, 162. [CrossRef]

14. Shaik, M.R.; Khan, M.; Kuniyil, M.; Al-Warthan, A.; Alkhathlan, H.Z.; Siddiqui, M.R.H.; Shaik, J.P.; Ahamed, A.; Mahmood, A.; Khan, M.; et al. Plant-Extract-Assisted Green Synthesis of Silver Nanoparticles Using Origanum vulgare L. Extract and Their Microbicidal Activities. Sustainability 2018, 10, 913.

15. Varikooty, J.; Keir, N.; Woods, C.A.; Fonn, D. Measurement of the refractive index of soft contact lenses during wear. Eye Contact Lens 2010, 36, 2-5. [CrossRef]

16. Childs, A.; Li, H.; Lewittes, D.; Dong, B.; Liu, W.; Shu, X.; Sun, C.; Zhang, H.F. Fabricating customized hydrogel contact lens. Sci. Rep. 2016, 6, 34905. [CrossRef]

17. Abdel-Halim, E.S.; Alanazi, H.H.; Al-Deyab, S.S. Utilization of hydroxypropyl carboxymethyl cellulose in synthesis of silver nanoparticles. Int. J. Biol. Macromol. 2015, 75, 467-473. [CrossRef] [PubMed]

18. Garza-Navarro, M.A.; Aguirre-Rosales, J.A.; Llanas-Vázquez, E.E.; Moreno-Cortez, I.E.; Torres-Castro, A.; González-González, V. Totally ecofriendly synthesis of silver nanoparticles from aqueous dissolutions of polysaccharides. Int. J. Polym. Sci. 2013, 436021. [CrossRef]

19. Oldenburg, S.J. Silver Nanoparticles: Properties and Applications, Sigma-Aldrich. Available online: www.sigmaaldrich.com/ technical--documents/articles/materials--science/nanomaterials/silver--nanoparticles.html.

20. Matuschek, E.; Brown, D.F.J.; Kahlmeter, G. Development of the EUCAST disk difusion antimicrobial susceptibility testing method and its implementation in routine microbiology laboratories. Clin. Microbiol. Infect. 2014, 20, o255-o266. [CrossRef] [PubMed]

21. Clinical and Laboratory Standards Institute (CLSI). Performance Standards for Antimicrobial Susceptibility Testing; Approved Standard, 25th Informational Supplement, CLSI document M100-S25; Clinical and Laboratory Standards Institute: Wayne, PA, USA, 2015.

22. Doroshenko, N.; Rimmer, S.; Hoskins, R.; Garg, P.; Swift, T.; Spencer, H.L.M.; Lord, R.M.; Katsikogianni, M.; Pownall, D.; MacNeil, S.; et al. Antibiotic functionalised polymers reduce bacterial biofilm and bioburden in a simulated infection of the cornea. Biomater. Sci. 2018, 6, 2101-2109. [CrossRef] [PubMed]

23. Karetsi, V.A.; Banti, C.N.; Kourkoumelis, N.; Papachristodoulou, C.; Stalikas, C.D.; Raptopoulou, C.P.; Psycharis, V.; Zoumpoulakis, P.; Mavromoustakos, T.; Sainis, I.; et al. An Efficient Disinfectant, Composite Material \{SLS@[Zn3(CitH)2]\} as Ingredient for Development of Sterilized and Non Infectious Contact Lens. Antibiotics 2019, 8, 213. [CrossRef] [PubMed]

24. Wiegand, I.; Hilpert, K.; Hancock, R.E.W. Agar and broth dilution methods to determine the minimal inhibitory concentration (MIC) of antimicrobial substances. Nat. Protoc. 2008, 3, 163-175. [CrossRef] [PubMed]

25. Zhu, B.; Zhu, S.; Li, J.; Hui, X.; Wang, G.-X. The developmental toxicity, bioaccumulation and distribution of oxidized single walled carbon nanotubes in Artemia salina. Toxicol. Res. 2018, 7, 897-906. [CrossRef] 
26. Banti, C.N.; Hadjikakou, S.K. Evaluation of Toxicity with Brine Shrimp Assay. Bio Protoc. 2020, 11, e3895. [CrossRef]

27. Trompeta, A.F.; Preiss, I.; Ben-Ami, F.; Benayahu, Y.; Charitidis, C.A. Toxicity testing of MWCNTs to aquatic organisms. RSC Adv. 2019, 9, 36707-36716. [CrossRef]

28. da Silveira Carvalho, J.M.; de Morais Batista, A.H.; Nogueira, N.A.P.; Holanda, A.K.M.; de Sousa, J.R.; Zampieri, D.; Bezerra, M.J.B.; Barreto, F.S.; de Moraes, M.O.; Batista, A.A.; et al. A biphosphinic ruthenium complex with potent anti-bacterial and anti-cancer activity. New J. Chem. 2017, 41, 13085-13095. [CrossRef]

29. Živković, M.B.; Matić, I.Z.; Rodić, M.V.; Novaković, I.T.; Sladić, D.M.; Krstić, N.M. Synthesis, characterization and in vitro cytotoxic activities of new steroidal thiosemicarbazones and thiadiazolines. RSC Adv. 2016, 6, 34312-34333. [CrossRef]

30. Ketikidis, I.; Banti, C.N.; Kourkoumelis, N.; Tsiafoulis, C.G.; Papachristodoulou, C.; Kalampounias, A.G.; Hadjikakou, S.K. Conjugation of Penicillin-G with Silver(I) Ions Expands Its Antimicrobial Activity against Gram Negative Bacteria. Antibiotics 2020, 9, 25. [CrossRef] 